УДК 378.2

DOI:

Володимир Мудрян, викладач кафедри фізичного виховання і спорту Донбаської державної машинобудівельної академї

\title{
ОСОБЛИВОСТІ ПІДГОТОВКИ ВЧИТЕЛІВ ФІЗИЧНОЇ КУЛЬТУРИ В УКРАЇНІ З ДРУГОЇ ПОЛОВИНИ ХХ СТ. ПО ТЕПЕРІШНІЙ ЧАС
}

У статті розглянуто в розрізі історичних аспектів особливості підготовки вчителя фізичної культури. Здійснено порівняльно-історичний аналіз радянського та сучасного спорту. Освітлені особливості та проблеми підготовки вчителів фізичної культури в розрізі другої половини ХХст. до натих днів, а так само знайдені $і$ запропоновані шляхи вирішення цих проблем. В системі вищої професійної освіти розглядається зміст професійної діяльності та моделі підготовки фахівия. Проведено порівняльноісторичний аналіз радянського та сучасного спорту.

Ключові слова: фізична культура; підготовка вчителів; фізичне виховання; фізична освіта; самовиховання.

Рис. 1. Табл. 1. Літ. 5.

Volodymyr Mudryan, Lecturer of the Physical Education and Sports Department Donbass State Machine-Building Academy

\section{FEATURES OF PREPARATION OFTEACHERS OF PHYSICAL CULTURE IN UKRAINE FROM THE SECOND HALF OF XX CENTURY TO PRESENT DAYS}

The article considers the feature of preparation of teacher of physical culture in terms of historical aspects. The comparatively-historical analysis of soviet and modern sport is carried out. The features and problems of preparation of teachers of physical culture are lighted up in the context of the second half of 20 centuries to our days, and similarly found and offered the way of decision of these problems. Maintenance of professiogrammy and models of preparation of specialist is considered in the system of higher professional education. The comparative-historical analysis of Soviet and modern sports is carried out. Conception and analysis of historical aspects and use of the experience of past years in preparation of teachers of physical culture and sports have been carried out. It is proved that this is an important and relevant part of the development and stable functioning of the system of physical education and sport in higher vocational education in Ukraine. Physical self-education is a deliberate process of conscious and systematic work of the future teacher over ones personality, which should reflect: the actual needs of physical education and personal development; the condition and the result of an effective process of physical education; the relationship of special disciplines of physical education throughout the period of on-study in higher education, based on which, on the one hand-the pedagogical leadership, and on the other - the influence of self-education. The success of the professional training of the future teacher of physical excitement is facilitated by a program of orientation of physical selfeducation, which sets the following objectives: to achieve comprehensive physical development and preparedness; Organize and introduce a healthy lifestyle; to participate in diverse physical-cultural-recreational activities; to form volitional, organizational and co-communicating abilities of an individual; to master the basic methods of physical self-education of schoolchildren.

Keywords: physical education; training of teacher; physical education; physical education; self-education.

П остановка проблеми. Однією 3 головних складових життя людини $€$ здоров’я. Вчителі фізичної підготовки грають велику роль в розвиток і збереження здоров'я школярів і студентів. 3 плином часу проблема підготовки вчителів фізичної культури набирає актуальності. Осмислення і аналіз історичних аспектів та використання досвіду минулих років - $\epsilon$ важливою і актуальною частиною розвиткуі стабільного функціонування системи фізичного виховання.

Аналіз останніх досліджень і публікацій. Проблемам підготовки вчителів фізичної культури II половини XX ст. присвятили свої роботи, такі вітчизняні автори, як Л.П.Сущенко, зокрема у роботі 2001 року“"Професійна підготовка фахівців фізичного виховання і спорту: історичний аспект", О.М. Вацеба та А.О. Кухтій, зокрема у роботі "Характеристика основ розвитку фізичної культури і спорту у вітчизняній та сучасній українській науково-методичній думці”, М. Крук, Б.М. Шиян, Р.В. Клопова та інші.

Метою даного дослідження $€$ аналіз історичних аспектів підготовки вчителів фізичної культури з 1950 року до сьогодні.

Для досягнення мети необхідно вирішити наступні завдання:

1. Розглянути в розрізі історичних аспектів 


\section{ОСОБЛИВОСТІ ПІДГОТОВКИ ВЧИТЕЛІВ ФІЗИЧНОЇ КУЛЬТУРИ В УКРАЇНІ З ДРУГОЇ ПОЛОВИНИ ХХ СТ. ПО ТЕПЕРІШНІЙ ЧАС}

особливості підготовки вчителя фізичної культури;

2. Здійснити порівняльно-історичний аналіз радянського та сучасного спорту;

3. Освітлити особливості та проблеми підготовки вчителів фізичної культури в розрізі другої половини XX ст. до наших днів;

4. Знайти і запропонувати шляхи вирішення проблем;

5. Зробити висновки.

Виклад основного матеріалу. Протягом всієї історії, фізична культура займала завжди одне 3 перших місць в житті і культурі людини. Наші предки доклали багато зусиль, щоб тодішня і нинішня молодь розвивалася і мала здоровий організм.

Після Другої світової війни посилено спортові контакти із Заходом, розгорнуто масовий фізкультурний рух, підвищено рівень спортивної майстерності. У зв'язку з цим посилився і фізкультурний рух в УРСР [1].

В кінці 40-х - початку 50-х рр. завдання фізкультурних організацій були скориговані 3 урахуванням престижу радянського спорту на міжнародній арені.

3 1954/55 навчального року вводиться нова програма 3 фізичної культури для початкових, говорилося про необхідність приділяти більше уваги спорту, гімнастика та легка атлетика виділялися в самостійні розділи.

У програмі 1954 року на предмет “Фізична культура” у всіх класах відводилося 66 годин на рік (по 2 години на тиждень).

У 1975 р була підготовлена і затверджена нова, вдосконалена програма. У 9 - 10-х класах нею передбачалося “.... навчити новим видам рухів 3 розділів гімнастики, легкої атлетики, лижної підготовки, класичної (греко-римської) боротьби, спортивних ігор, удосконалювати вміння семирічних і середніх шкіл. У програмі, зокрема,

застосовувати їх в різних по складності умовах, розвивати необхідні для цього рухові якості”.

У 1985/86 навчальному році була введена “Комплексна програма фізичного виховання учнів 1 - 11-х класів загальноосвітньої школи". Як і раніше, вона була єдиною для всіх шкіл країни $і$ називалася комплексною. Фактично вона об’єднала різні форми рухової активності школярів, раніше вже включені в практику роботи шкіл [2].

У 90-х pp. XX - початку XXI ст. основними напрямами вдосконалення галузі фізичної культури й спорту визнано збереження та подальше вдосконалення матеріально-спортивної бази, підготовку фахівців фізичного виховання й спорту, науково-методичного та інформаційного забезпечення фізкультурно-спортивної діяльності; стимулювання фізкультурно-оздоровчої діяльності в навчально-виховній сфері; сприяння розвитку масового фізкультурно-спортивного руху.

На початку XXI ст. Міністерством освіти і науки України та педагогічними ВНЗ проводилася плідна робота зі створення національних освітніх стандартів, які б визначали головні риси педагогічних працівників у новому тисячолітті. Зокрема, внесено значні зміни в навчальні плани, запроваджено нові експериментальні навчальні програми та комплекти навчально-методичного забезпечення для факультетів фізичного виховання. У кожному педагогічному ВНЗ створювались оптимальні моделі теоретичної та методичної підготовки майбутніх учителів фізичної культури [3].

В сучасній Україні навчальні заклади по підготовці фахівців за профілем фізичної культури ставить перед собою завдання вдосконалення системи підготовки викладачів. 3 плином часу, 3 соціальними змінами в суспільстві, зростають і вимоги до майбутніх фахівців.

Розкриваючи дану тему виникає необхідність в порівняльно-історичному аналізі радянського спорту та сучасного (таблиця 1).

Таблиця 1.

Порівняння радянського та сучасного спорту

\begin{tabular}{|c|c|c|}
\hline Зміст & $\begin{array}{l}\text { Фізичної культури } \\
\text { радянської України }\end{array}$ & $\begin{array}{c}\text { Фізична куль- } \\
\text { тура сучасної України }\end{array}$ \\
\hline & \multicolumn{2}{|c|}{ Позначка } \\
\hline $\begin{array}{c}\text { Доступність до відвідування гуртка, який зміцнює } \\
\text { здоров’я та близький по духу. }\end{array}$ & + безкоштовно & платно \\
\hline Кількість шкіл з підготовки фахівців & + & + \\
\hline Заняття спортом & $\begin{array}{c}\text { +Раній інтерес дітей до } \\
\text { здорового способу } \\
\text { життя. }\end{array}$ & $\begin{array}{c}\text { - Невелика кількість } \\
\text { підлітків зацікав- } \\
\text { лених в спорті }\end{array}$ \\
\hline $\begin{array}{l}\text { Інноваційність, автоматизація, науково-технічний } \\
\text { прогрес }\end{array}$ & $\begin{array}{l}\text { - притримування } \\
\text { стабільності }\end{array}$ & $\begin{array}{c}+ \text { розвиток нових } \\
\text { інноваційних видів } \\
\text { спорту }\end{array}$ \\
\hline
\end{tabular}




\section{ОСОБЛИВОСТІ ПІДГОТОВКИ ВЧИТЕЛІВ ФІЗИЧНОЇ КУЛЬТУРИ В УКРАЇНІ З ДРУГОЇ ПОЛОВИНИ ХХ СТ. ПО ТЕПЕРІШНІЙ ЧАС}

Отже, у радянського спорту і у сучасного $є$ свої позитивні моменти. При поєднанні позитивних аспектів тодішнього і теперішнього періодів вийде ідеальна система.

Від радянського спорту необхідно запозичити доступність відвідування спортивних секцій та залучення молоді до спорту, від сучасного-НТП.

На сьогодні вчитель фізичного виховання у роботі зі студентами повинен виконувати такі пункти:

1. Розвиток та формування у студентів спеціальної гуманітарної підготовки;

2. Розвиток та покращення фізичної підготовки студентів;

3. Пропаганда викладачем здорового способу життя у студентів;

4. Використання сучасних інноваційних технологій у процесі підготовки студентів.

Піднімаючи тему підготовки вчителя фізичної культури, не можна обійти проблему професійної майстерності майбутнього вчителя. Ця проблема займає головне місце в підготовці фахівців.

У ВНЗ, та після ВНЗ, майбутній вчитель фізичної культури, для підвищення професійної майстерності, повинен володіти суспільними дисциплінами, профільними та педагогічними.

Процес професійної підготовки майбутнього вчителя можна поділити на 3 групи: підготовка до ВНЗ, у ВНЗ та після ВНЗ (рис. 1) освіти й розвитку особистості; умову та результат ефективного процесу фізичного виховання; взаємозв'язок спеціальних дисциплін фізичного виховання протягом усього періоду навчання у ВНЗ, в основі якого, з одного боку - педагогічне керівництво, а 3 другого - вплив самовиховання [5].

Успіху професійної підготовки майбутнього вчителя фізичного виховання сприяе програмаорієнтир фізичного самовиховання, яка ставить такі завдання: досягти всебічного фізичного розвитку й підготовленості; організувати та впровадити здоровий спосіб життя; брати участь у різнобічній фізкультурно-оздоровчій діяльності; формувати вольові, організаторські й комунікативні здібності особистості; оволодіти основними методами фізичного самовиховання школярів. Щоб виконати ці завдання, студент майбутній учитель фізичного виховання повинен:

- ознайомитися 3 науково-методичною літературою з питань фізичного самовиховання;

- постійно формувати особистість майбутнього вчителя засобами фізичної культури та спорту, у повсякденному житті використовувати фізичні вправи, займатися туризмом і спортом;

- дотримуватися режиму харчування й відпочинку;

- почергово замінювати працю на відпочинок із використанням фізичних вправ;

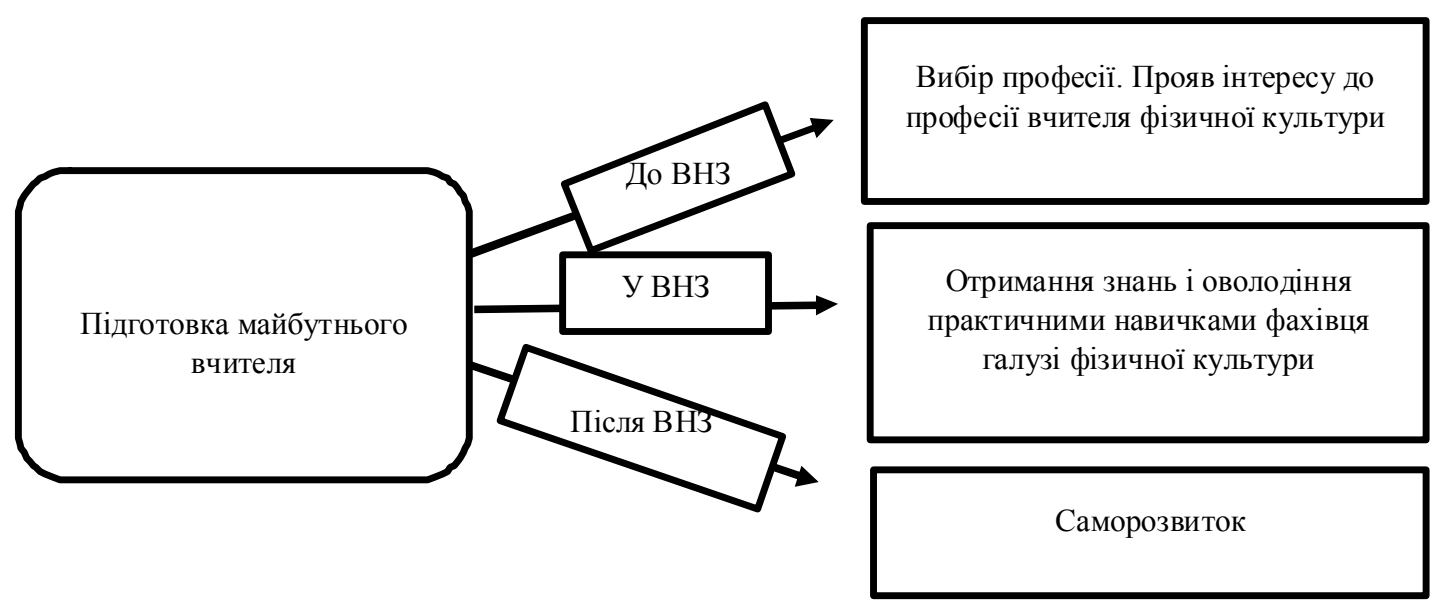

Рис. 1. Процес підготовки майбутнього вчителя фізичної культури

Окремим етапом і найбільш важливим є все таки саморозвиток, або самовиховання. Воно присутнє на всіх етапах і найбільш вагоме після закінчення ВНЗ.

Фізичне самовиховання - це цілеспрямований процес свідомої та планомірної роботи майбутнього вчителя над своєю особистістю, яке повинно відображати: актуальні потреби фізичної
- відмовитися від шкідливих звичок;

- самостійно займатися фізичною культурою та спортом;

- організовувати виховну роботу зі школярами за допомогою засобів фізичної культури й спорту;

- брати участь у керівництві фізичним самовихованням школярів.

Застосування розвитку процесу самовиховання 


\section{ОСОБЛИВОСТІ ПІДГОТОВКИ ВЧИТЕЛІВ ФІЗИЧНОЇ КУЛЬТУРИ В УКРАЇНІ З ДРУГОЇ ПОЛОВИНИ ХХ СТ. ПО ТЕПЕРІШНІЙ ЧАС}

визначає характер роботи над собою кожної особистості й, безумовно, сприяє професійнопедагогічній підготовці вчителя фізичної культури до майбутньої роботи [4].

Для вирішення проблеми професійної майстерності майбутнього вчителя перш за все необхідно:

1. Підвищення зацікавленості та готовності до вирішення даної проблеми державних установ, трудових колективів і безпосередньо самих вчителів фізичної культури;

2. Рішення даної проблеми на ранньому етапі в сім’ї. Участь батьків у вихованні у дитини навичок і здібностей цілеспрямованості. Залучення до фізичної культури [5].

Висновки. Питання підготовки кадрів 3 фізичної культури були i залишаються актуальними. Завдяки запозичення ідей 3 минулого і використання інноваційних технологій можливо і реально досягнення стабільної, хорошої, системи підготовки фахівців фізичної культури.

В останні роки діти, підлітки і студенти все більше цікавляться не спортом, а комп'ютерними іграми, через що, в основному, гублять своє здоров'я. Завдяки професійності та майстерності викладачів фізичної культури можна прищепити підліткам любов до спорту і, відповідно, повернути в норму їх організм, тому що спорт i здоровий спосіб життя-шлях до процвітання нації.

\section{ЛІТЕРАТУРА}

1. Історія розвитку фізичного виховання в Україні [Електронний ресурс]/УФХ: інформ.довідковий портал. 2010. URL: $\underline{\mathrm{http}: / /}$ www.horting.org.ua/node/1642

2. Шкільні програми 3 фізичної культури в 1950-1980 рік[Електронний ресурс]/Книги для вcix. URL:http://lib4all.ru/base/B3139/B3139Part25188.php

3. Проніков О. Підготовка вчителя фізичної культури. Досвід та перспектива/О.Проніков // Фізичне виховання, спорт і культура здоров'я у сучасному суспільстві: збірник наукових праць.2015.- № 1 (29).

4. Юр'єва Л., Сава М., Яворський Ю. Особливості професійної майстерності майбутнього фахівця фізичної культури / Лариса Юр'єва, Микола Сава, Юрій Яворський//Фізичне виховання, спорт і культура здоров'я у сучасному суспільстві: збірник наукових праць. - 2009. - №3.

5. Сущенко Л. П. Професійна підготовка майбутніх фахівців фізичного виховання та спорту (теоретико-методологічний аспект): монографія / Л. П. Сущенко. - Запоріжжя: ЗДУ, 2003. - 442 с.

\section{REFERENCE}

1. Istoriia rozvytku fizychnoho vykhovannia $\mathrm{v}$ Ukraini (2010). [History of the development of physical education in Ukraine]. [Electronic resource]. URL: http://www.horting.org.ua/node/1642 [in Ukrainian].

2. Shkilni prohramy z fizychnoi kultury v 19501980-e rik [School curriculums in physical culture in the 1950s-1980s]. [Electronic resource]. URL:http:// lib4all.ru/base/B3 139/B3139Part25-188.php[in Ukrainian].

3. Pronikov, O. (2015). Pidhotovka vchytelia fizychnoi kultury. Dosvid ta perspektyva [Teacher Physical Training. Experience and Perspectives]. Physical education, sports and health culture in modern society: a collection of scientific works, no. 1 (29). [in Ukrainian].

4. Iurieva, L., Sava, M. \& Yavorskyi, Yu. (2009). Osoblyvosti profesiinoi maisternosti maibutnoho fakhivtsia fizychnoi kultury [Features of professional skill of future specialist of physical culture]. Physical education, sports and health culture in modern society: a collection of scientific work, no.3. [in Ukrainian].

5. Sushchenko, L. P. (2003). Profesiina pidhotovka maibutnikh fakhivtsiv fizychnoho vykhovannia ta sportu (teoretyko-metodolohichnyi aspekt) [Professional training of future specialists in physical education and sport (theoretical and methodological aspect)]. Zaporizhzhia: ZDU, 442 p. [in Ukrainian].

Стаття надійшла до редакції 02.03.2018

\section{G5808}

"Найсқладніша річ - вимогливість до себе".

Антон Макаренко

украйнський педагог

“Свої здібності людина може пізнати, лише спробувавши їхвикористати”. 